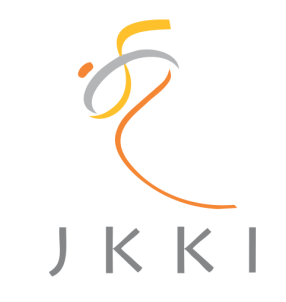

Jurnal Kedokteran dan Kesehatan Indonesia

Indonesian Journal of Medicine and Health

SCIEMTIR EST BASIC VITAE

Journal homepage: https://journal.uii.ac.id/JKKI

\title{
Public knowledge of self-medication in Ngaglik subdistrict of Sleman regency
}

Dian Medisa ${ }^{1}$, Fithria Dyah Ayu Suryanegara*1, Ditya Ayu Natalia ${ }^{1}$, Puspita Fitri Handayani ${ }^{1}$, Dhea Putri Indra Kusuma ${ }^{1}$, Diesty Anita Nugraheni ${ }^{1}$

${ }^{1}$ Department of Pharmacy, Faculty of Mathematics and Natural Sciences, Universitas Islam Indonesia, Yogyakarta, Indonesia

Original Article

\begin{tabular}{l}
\hline \\
\hline ARTICLE I N F O \\
\hline Keywords: \\
knowledge, \\
self-medication, \\
Sleman Regency \\
*Corresponding author: \\
106130101@uii.ac.id \\
\hline D0I: 10.20885/JKKI.Vol11.Iss3.art6 \\
\hline History: \\
Received: June 6, 2020 \\
Accepted: December 29, 2020 \\
Online: December 31, 2020 \\
Copyright @2020 Authors. \\
This is an open access article \\
distributed under the terms \\
of the Creative Commons At- \\
tribution-NonCommercial 4.0 \\
International Licence (http:// \\
creativecommons.org/licences/ \\
by-nc/4.0/).
\end{tabular}

ABSTRACT

Background: Self-medication is using medicines without a prescription or health professional advice. Over-the-counter (OTC) medicines are commonly used in self-medication. Knowledge and practices of selfmedication is required to be assessed to ensure appropriate uses of medicines.

Objective: This study is to examine public knowledge and practices of self-medication in Subdistrict of Ngaglik, Sleman, D.I. Yogyakarta.

Methods: A cross-sectional survey was conducted in three villages in Ngaglik, Sleman. 339 participants were selected through a cluster sampling. Data were collected by using a self-administered questionnaire. Descriptive analysis and chi-square test were used to analyse the data.

Results: Most of participants were female (61.7\%) aged between 26-45 years (49.9\%). More than fifty percent of participants (59\%) had education level of senior high school, and $49.9 \%$ participants had good knowledge of the OTC self-medication. The level of knowledge of self-medication was significantly associated with the level of education ( $p$ values $<0.05$ ). The most commonly used OTC medicines for self-medication were analgesics and antipyretics (48.4\%), respiratory drugs (29.7\%), and gastrointestinal drugs (9.6\%). OTC medicine advertisements were common sources of information about medicines for self-medication (39.5\%) whereas information sources from health professionals were accounted for only $2.4 \%$.

Conclusion: The public knowledge of self-medication needs to be developed. Health professionals, especially pharmacists, are suggested to provide more information on the OTC medicines for public to allow them to access additional information sources than medicine advertisements.

Latar Belakang: Pengobatan sendiri atau swamedikasi adalah penggunaan obat tanpa resep dokter. Golongan obat bebas dan bebas terbatas merupakan obat yang paling sering digunakan untuk swamedikasi. Pengukuran pengetahuan masyarakat tentang swamedikasi penting dilakukan untuk menjamin penggunaan obatyang tepat.

Tujuan: Penelitian ini bertujuan untuk mengetahui tingkat pengetahuan dan perilaku masyarakat tentang swamedikasi di Kecamatan Ngaglik, Kabupaten Sleman.

Metode: Penelitian cross-sectional dilakukan di 3 desa di Kecamatan Ngaglik, Kabupaten Sleman. Jumlah responden sebanyak 339 yang dipilih menggunakan metode cluster sampling. Data diperoleh dari pembagian kuesioner yang telah tervalidasi kepada responden. Analisis data menggunakan analisis despriktif dan uji chi-square. 
Hasil: Mayoritas peserta adalah perempuan (61,7\%) dan berusia 26-45 tahun (49,9\%). Lebih dari lima puluh persen responden (59\%) berpendidikan SMA. Persentase responden yang memiliki tingkat pengetahuan baik tentang swamedikasi (49,9\%). Pengetahuan tentang swamedikasi berhubungan dengan tingkat pendidikan $(p<0,005)$. Obat yang sering digunakan untuk swamedikasi adalah analgetik dan antipiretik (48,4\%), obat saluran pernafasan $(29,7 \%)$, dan obat pencernaan $(9,6 \%)$. Responden paling banyak mendapatkan informasi tentang obat untuk swamedikasi dari iklan obat, sedangkan yang mendapatkan informasi dari tenaga kesehatan hanya 2,4\%.

Kesimpulan: Pengetahuan masyarakat tentang swamedikasi masih perlu ditingkatkan. Tenaga kesehatan, terutama apoteker, harus lebih pro-aktif memberikan informasi kepada masyarakat terkait obat-obat yang digunakan oleh masyarakat.

\section{INTRODUCTION}

Self-medication is one of the self-care practices using non-prescription medicines commonly practiced by the public as an effort to maintain their health. Basic health research of 2013 showed that $35.2 \%$ households in Indonesia kept medicines at home for selfmedication. ${ }^{1}$ Meanwhile, $85 \%$ of them did not have appropriate knowledge of generic medicines. Based on Widayati's research in 2011, 44\% people in Yogyakarta Special Province practiced self-medication for some reasons, such as previous successful selfmedication, minor illness perception, time saving, and money saving. ${ }^{2}$ Self-medication is defined as the selection and use of medicines by individuals to treat self-recognized diseases or symptoms without prior medical consultation. ${ }^{3}$ Some people choose self-medication by seeking OTC (Over The Counter) medicines to relieve symptoms. ${ }^{4}$

Self-medication requires a certain level of knowledge of medicines since it carries the risks of socioeconomic and individual health status. Self-medication may result in adverse drug events that require medical intervention. ${ }^{5}$ There were $1.3 \%$ people experiencing adverse drug events while practicing self-medication, and three out of four were reported as severe. ${ }^{6}$ Inappropriate self-medication can increase the risk of drug misuse and delay in obtaining medical intervention due to the masking of some symptoms. ${ }^{7}$ Self-medication has an association with levels of education. Lacking knowledge of self-medication can lead to inappropriate self-medication that harms an individual's health status. ${ }^{8}$ The research about community knowledge on drug storage and disposal is limited, especially in Indonesia, so that we conducted the study about self-medication, include how to get, how to use, the storage, and the disposal of medicines. The objective of this study was to investigate the public knowledge and practices of self-medication in Ngaglik Subdistrict of Sleman Regency.

\section{METHODS}

\section{Study design}

A cross-sectional study was conducted in 3 villages in Ngaglik Subdistrict of Sleman Regency. This study was approved by the Medical and Health Research Ethics Committee (MHREC) of the Faculty of Medicine Gadjah Mada University number KE/FK/0641/EC/2018.

\section{Sample size}

A total of 339 participants were selected using the clustered random sampling method. The inclusion criteria were individuals aged 18-65 years old who agreed to fill out the inform consent and have used OTC medicines for a minimum of one month. Healthcare professionals were excluded from the study. The participants became the representative of each household visited by the researcher.

\section{Study setting}

A structured questionnaire was developed upon completing the literature review, consisting of three sections of sociodemographic characteristics, OTC self-medication knowledge, and self-medication practices. The knowledge section contained 4 domains, including how to get, how to use, the storage, and the disposal 
of medicines. In addition, the self-medication behavior questions included the most commonly used medicines for self-medication and the source of information about OTC medicines. Content validity was done to ensure the questionnaire validity. The questionnaire was also distributed to 30 respondents who met the inclusion criteria for a pilot study to confirm the validity and reliability. Some of the wording was modified in a number of questions to achieve high consistency and reliability (Cronbach's alpha $=0.84$ ).

The data were collected through a selfadministered questionnaire. Only one person could be the participant from each household. The aims of this study and confidentiality were explained to the participants, and they should fill out the questionnaire on the spot accompanied by the researcher or facilitator.

\section{Data analysis}

A descriptive analysis and chi-square test were performed to analyze the data. The knowledge questions had two responses ("yes" and "no"). Each response was scored for data analysis where score 1 was given to correct answer and score 0 was for incorrect answer. The level of knowledge was categorized

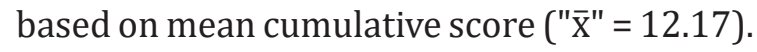
Participants who had a cumulative score equal or above the mean score were categorized into "good knowledge", whereas those with a cumulative score below the mean score was considered in "poor knowledge". Chi-square test was used to analyze the association between level of knowledge and socio-demographic characteristics $(\mathrm{p}<0.05)$.

\section{RESULTS \\ Demographic characteristics}

The total number of participants in this study was 339 respondents, and most of them were female $(61.7 \%)$ with only $38.3 \%$ male. The age distribution was 17-25 years (22.7\%), 26-45 years (49.9\%), and 46-65 years (27.4\%). More than fifty percent participants (59.0\%) attended senior high school, and the rest attained the highest level in university (18.9\%), junior high school (13.3\%), and elementary school (8.8\%).

\section{Participant's practices of self-medication}

All of the participants in this study used OTC medicines for self-medication. A total of 202 participants (48.4\%) used analgesics and antipyretics for self-medication, followed by respiratory drugs taken by 124 participants (29.7\%). The other medicines included gastrointestinal medicines (40 participants/9.6\%), herbal preparation (33 people/7.9\%), and anti-allergic drugs (4 people/1\%). The analgesics and antipyretics were most likely used to treat headache and fever with paracetamol as the most commonly used medicine. The sources of information about OTC medicines came from advertisements $(39.5 \%)$, family $(23.6 \%)$, friends $(18.3 \%)$, references $(2.4 \%)$, healthcare professionals (2.4\%), and others (13.9\%).

\section{Knowledge of self-medication}

The level of knowledge of OTC medicines for self-medication is explained in Table 1. Overall, 49.9\% participants had good knowledge whereas $50.1 \%$ had poor knowledge. There was a correlation between knowledge and level of education $(\mathrm{p}<0.05)$, while gender, age, and occupation had no relationships with knowledge $(\mathrm{p}>0.05)$ (Table 2).

\section{DISCUSSION}

This study revealed that analgesics and antipyretics were the most commonly used in OTC self-medication practices followed by respiratory drugs. Other studies showed a similar result in that the majority of people used paracetamol to treat headache and fever, whereas respiratory drugs were for treating common cold. ${ }^{9-11}$ The primary source of information about the medicines used for selfmedication was medicine advertisements while only a few participants sought information from pharmacists. This result contradicted a study in Taiwan which found that pharmacists became the primary source of information on medicines. ${ }^{7}$ 
Table 1. Percentage of correct response about knowledge of self-medication

\begin{tabular}{|c|c|c|}
\hline \multirow{2}{*}{ Questions domain } & \multicolumn{2}{|c|}{ Correct response from participants } \\
\hline & Frequency & Percentage (\%) \\
\hline \multicolumn{3}{|l|}{ How to get medicines } \\
\hline All medicines can be bought in a supermarket & 279 & 82.3 \\
\hline We can get medicines from family or friends & 270 & 79.6 \\
\hline Antibiotics can be bought in a supermarket & 262 & 77.3 \\
\hline \multicolumn{3}{|l|}{ The use of medicines } \\
\hline Paracetamol is used for fever only & 143 & 42.2 \\
\hline $\begin{array}{l}\text { The meaning of twice daily is taking medicines in the morning } \\
\text { and afternoon }\end{array}$ & 61 & 18 \\
\hline $\begin{array}{l}\text { Syrup is allowed to be used anytime as long as its physical } \\
\text { appearance does not change }\end{array}$ & 226 & 66.7 \\
\hline Sore throat is treated using mucolytics & 184 & 54.3 \\
\hline Povidone iodine is used to treat wound before it is cleaned & 253 & 74.6 \\
\hline Eye-drop medicines can be directly dripped on the cornea & 125 & 36.9 \\
\hline \multicolumn{3}{|l|}{ Medicine storage } \\
\hline Suppositories are stored in the medicine cabinet & 245 & 72.3 \\
\hline All OTC medicines can be stored in the refrigerator & 238 & 70.2 \\
\hline Medicines can be stored in a non-original packaging & 289 & 85.3 \\
\hline $\begin{array}{l}\text { Eye drops can be stored for more than one month after opening } \\
\text { the seal }\end{array}$ & 210 & 61.9 \\
\hline $\begin{array}{l}\text { Liquid dosage form medicines are stored in the refrigerator to } \\
\text { maintain their stability }\end{array}$ & 162 & 47.8 \\
\hline \multicolumn{3}{|l|}{ Medicine disposal } \\
\hline $\begin{array}{l}\text { Medicines must be removed from the packaging at the time of } \\
\text { disposal }\end{array}$ & 200 & 59.0 \\
\hline $\begin{array}{l}\text { Liquid medicines in the package can be directly disposed of in } \\
\text { the trashcan }\end{array}$ & 189 & 55.8 \\
\hline All expired medicines can be disposed of in the trashcan & 141 & 41.6 \\
\hline Drug packaging in a cardboard form must be cut before disposal & 226 & 66.7 \\
\hline Tablets must be crushed before disposal & 205 & 60.5 \\
\hline Tablets are disposed by being buried in the ground & 218 & 64.3 \\
\hline
\end{tabular}

*Total number of participants: 339 respondents

Most of the participants already had good knowledge of the place for getting OTC medicines. More than half bought OTC medicines from a pharmacy (74.6\%), and others went to a drug store and supermarket. The source to obtain drugs for self-medication was the same as that revealed in a study in Purbalingga and systematic review by Limaye et al. in which most of the respondents purchased medicines at the pharmacy. ${ }^{12,13}$ The public should be more encouraged to buy medicines at the pharmacy to ensure that the medicines are of good quality and the public receives information about medicines from pharmacists.

The knowledge of medicine use among the community members in Ngaglik should be 
Table 2. Correlation between sociodemographic characteristics and knowledge of self-medication

\begin{tabular}{|c|c|c|c|c|c|}
\hline \multirow{2}{*}{$\begin{array}{l}\text { Sociodemographic } \\
\text { characteristic }\end{array}$} & \multirow{2}{*}{$\begin{array}{c}\text { Knowledge } \\
\text { score }\end{array}$} & \multicolumn{2}{|c|}{$\begin{array}{l}\text { Self-medication } \\
\text { knowledge level }\end{array}$} & \multirow[t]{2}{*}{ Total } & \multirow{2}{*}{ P-value } \\
\hline & & Good & Poor & & \\
\hline \multicolumn{6}{|l|}{ Gender } \\
\hline Male & $12.23 \pm 3.39$ & $62(47.7)$ & $68(52.3)$ & $130(100)$ & 0.606 \\
\hline Female & $12.13 \pm 3.17$ & $107(51.2)$ & $102(48.8)$ & $209(100)$ & \\
\hline \multicolumn{6}{|l|}{ Years of age } \\
\hline $18-36$ & $12.19 \pm 3.09$ & $84(49.4)$ & $86(50.6)$ & $170(100)$ & 0.957 \\
\hline $37-65$ & $12.15 \pm 3.42$ & $85(50.3)$ & $84(49.7)$ & $169(100)$ & \\
\hline \multicolumn{6}{|l|}{ Educational attainment } \\
\hline Lower than Senior High School & $11.12 \pm 3.37$ & $26(34.7)$ & $49(65.3)$ & $75(100)$ & $0.004^{*}$ \\
\hline Senior High School and University & $12.47 \pm 3.17$ & $143(54.2)$ & $121(45.8)$ & $264(100)$ & \\
\hline \multicolumn{6}{|l|}{ Occupation } \\
\hline Employed & $12.11 \pm 3.33$ & $98(49.5)$ & $100(50.5)$ & $198(100)$ & 0.963 \\
\hline Unemployed & $12.25 \pm 3.14$ & $71(50.4)$ & $70(49.6)$ & $141(100)$ & \\
\hline
\end{tabular}

improved. Most of them did not understand that paracetamol is not only for fever but also for pain treatment. A study in India showed a similar result in that only $6.8 \%$ participants had good knowledge of paracetamol use. ${ }^{14}$ Moreover, only $18 \%$ participants gave correct response about the time to administer medicines. This has to be an essential concern since the appropriate time of medicine administration is correlated with the dosage. ${ }^{15}$ Medicine indications, interactions, side effects, and other information must be clearly understood for the efficacy and safety of OTC self-medication. Therefore, health professionals, especially pharmacists, should provide medicine information for patients or community members about how to practice self-medication appropriately and the impacts if it is not done properly, thereby improving health literacy.

A qualitative study found that it is a challenge for a pharmacist with limited time has to communicate with the patient through simplified information. In the population with low health literacy, they will not necessarily self-identify and sidestep to the pharmacy. Theeffective pharmacist interventions require to inquire patients in their neighborhood, for example, pharmacy home visits or community groups. ${ }^{16}$ Besides, Manchanayake et al, showed that most-often the pharmacist assumed that patients are adequate to read and recognize dosing directions, but the study points out that several dosing directions were misread or misunderstood. They suggested the need for dosing directions standard and advised pharmacists to give the medication information to the patients considering their demographics such as age, education level, functional and language barriers. ${ }^{17}$

Medicine storage and disposal are also essential to be understood by the public practicing self-medication. The participants still had a lack of knowledge of liquid dosage form and eye drops storage. More than 50\% participants thought that all liquid dosage form could be stored in the refrigerator. A study in Taiwan also found that some people believed that all types of medicine could be stored in the refrigerator. ${ }^{7}$ Furthermore, the knowledge of medicine disposal should be improved because inappropriate medicine disposal will lead to pollution, thus putting the public at risk. . $^{18,19}$

The participants' knowledge of selfmedication can be affected by sociodemographic 
characteristics. ${ }^{20}$ In this study, the knowledge was significantly associated with level of education. The highest score of knowledge was achieved by the participants who had a university background. Previous studies revealed the relationship between education and knowledge. ${ }^{20-22}$ People with higher education are more likely to access different sources of information compared to those with low education attainment. ${ }^{20}$

\section{Strengths and limitations of the study}

This study has the strength of the topic of knowledge measurement. It measured not only the knowledge of how to use OTC but also that of how to get, how to store, and how to dispose OTC medicines used in self-medication. The limitation of the study, on the other hand, is caused by the lack of funding. The area of the study only covered 3 villages in Ngaglik Subdistrict while it would be far better if the study was carried out over a wider area.

\section{CONCLUSION}

The public knowledge of self-medication still needs improving. Health professionals, pharmacists, in particular, should give more information to the public about OTC medicines to prevent them from obtaining information only from medicine advertisements. The interventions could be direct to the patient with provided clear medication information, or through the community groups. A quasiexperimental study is required for future research to investigate the improvement in the knowledge among participants after receiving education intervention using a pre-test and post-test.

\section{CONFLICT OF INTEREST}

Theres is no conflict of interest in this study.

\section{ACKNOWLEDGEMENT}

None declare.

\section{REFERENCES}

1. Kemenkes. Riset kesehatan dasar 2013. Jakarta: Badan Penelitian dan Pengemban- gan Kesehatan Departemen Kesehatan Republik Indonesia. 2013. 40 p.

2. Widayati A, Suryawati S, Crespigny C, Hiller J. Self medication with antibiotics in Yogyakarta City Indonesia: A cross sectional population-based survey. BMC Research Notes. 2011;4(1):491.

3. Agabna N, Osman A, Arabi A, Alsaddig R, Mohamed E, El-Kheir H, et al. Self-medication. Sudan Journal of Rational Use of Medicine. 2014;(6):4.

4. Sawalha AF. Assessment of self-medication practice among university students in Palestine: Therapeutic and toxicity implications. The Islamic University Journal (Series of Natural Studies and Engineering). 2007;15(2):67-82.

5. Ruiz M. Risks of self-medication practices. Current Drug Safety. 2010;5(4):315-23.

6. Stevenson R, Walter R, Harmse J, Wilson E. Mortality during the winter flu epidemic-Two cases of death associated with self-medication. Scottish Medical Journal. 2001;46(3):84-6.

7. Lee $\mathrm{CH}$, Chang FC, Hsu S Der, Chi HY, Huang LJ, Yeh MK. Inappropriate self-medication among adolescents and its association with lower medication literacy and substance use. PLoS One. 2017;12(12):1-14.

8. Jamhour A, El-Kheir A, Salameh P, Hanna PA, Mansour H. Antibiotic knowledge and self-medication practices in a developing country: A cross-sectional study. American Journal of Infection Control. 2017;45(4):384-8.

9. Adhikary M, Tiwari P, Singh S, Karoo C. Study of self medication practices and its determinant among college students of Delhi University North Campus, New Delhi, India. International Journal of Medical Science and Public Health. 2014;3(4):406.

10. Kumar V, Mangal A, Yadav G, Raut D, Singh S. Prevalence and pattern of self-medication practices in an urban area of Delhi, India. Medical Journal of Dr. D.Y. Patil University. 2015;8(1):16.

11. Tesfamariam S, Anand IS, Kaleab G, Berhane S, Woldai B, Habte E, et al. Self-medication with over the counter drugs, prev- 
alence of risky practice and its associated factors in pharmacy outlets of Asmara, Eritrea. BMC Public Health. 2019;19(1):1-9.

12. Fuaddah AT. Description of self-medication behavior in community of Subdistrict Purbalingga, District Purbalingga. Jurnal Kesehatan Masyarakat. 2015;3(1):610-8.

13. Limaye D, Limaye V, Krause G, Fortwengel G. A systematic review of the literature to assess self-medication practices. Annals of Medical and Health Sciences Research. 2017;7:1-15.

14. Dorji T, Gyeltshen K, Pongpirul K. Rational use of paracetamol among out-patients in a Bhutanese District hospital bordering India: A cross-sectional study. BMC Research Notes. 2018;11(1):1-6.

15. Patel MJ, Khan MS, Ali F, Kazmi Z, Riaz T, Awan S, et al. Patients' insight of interpreting prescriptions and drug labels - A cross sectional study. PLoS One. 2013;8(6):6-11.

16. Wali H, Grindrod K. Don't assume the patient understands: Qualitative analysis of the challenges low health literate patients face in the pharmacy. Research in Social and Administrative Pharmacy. 2016;12(6):885-92.

17. Manchanayake MGCA, Bandara GRWSK, Samaranayake NR. Patients' ability to read and understand dosing instructions of their own medicines - A cross sectional study in a hospital and community pharmacy setting. BMC Health Services Research. 2018;18(1):1-8.

18. Mani A, Thawani V. The persisting environmental problem of disposal of expired and unused medicines. Journal of Mahatma Gandhi Institute of Medical Sciences. 2019;24(1):13.

19. Wondimu A, Molla F, Demeke B, Eticha T, Assen A, Abrha S, et al. Household storage of medicines and associated factors in Tigray Region, Northern Ethiopia. PLoS One. 2015;10(8):1-9.

20. Dawood OT, Hassali MA, Saleem F. Factors affecting knowledge and practice of medicine use among the general public in the State of Penang, Malaysia. Journal of Pharmaceutical Health Services Research.
2017;8(1):51-7.

21. Pavydè E, Veikutis V, Mačiulienė A, Mačiulis V, Petrikonis K, Stankevičius E. Public knowledge, beliefs and behavior on antibiotic use and self-medication in Lithuania. International Journal of Environmental Research and Public Health. 2015;12(6):7002-16.

22. Alhaddad MS, Abdallah QM, Alshakhsheer SM, Alosaimi SB, Althmali AR, Alahmari SA. General public knowledge, preferred dosage forms, and beliefs toward medicines in western Saudi Arabia. Saudi Medical Journal. 2014;35(6):578-84. 